\title{
Creative Industry: Two Cases of Performing Arts Market in Indonesia and South Korea
}

\author{
Juju Masunah \\ Universitas Pendidikan Indonesia \\ Email: jmasunah@upi.edu
}

\begin{abstract}
This article explores the concepts and practices of performing arts market, one of the fifteen sub-sectors of creative industry in Indonesia. This study discusses two performances namely Indonesia Performing Arts Market (IPAM) 2013 in Indonesia and Performing Arts Market in Seoul (PAMS) 2015, South Korea. The data were collected through participatory observation, interview, literature review, and personal reflections. The data were analyzed by using triangulation, member check, compare and contrast, and interpretation. The findings of this research show that the similarity of the two performing arts markets lies in their concept of globalization in regards to world society. The performing arts markets share two similar targets, festival in the country and tour abroad. The main differences between IPAM and PAMS are the scope of the event and the institution holding the event. IPAM showcased the works of Indonesian performing arts, while PAMS showcased the works of Korean performing arts and the arts from other countries. IPAM 2013 was organized by the central government, while PAMS 2015 was organized by Korean Arts Management Services (KAMS) that was financially supported by the central government of South Korea.
\end{abstract}

Keywords: creative economy, creative industry, globalization, performing arts market

\section{INTRODUCTION}

Creative industry is one sector in the creative economy subsystem. The creative economy was mentioned by John Howkins as the $4^{\text {th }}$ wave in the evolution of the structure of its production (Ministry of Tourism and Creative Economy, 2014a: 4), after the first wave which was the agricultural economy, the second wave which was the industry economy, and the third wave which was information economy. Study of creative industry mostly focuses on employment and business activities in the field of selected industrial classifications (Higg \& Cunninghum, 2008). Creative industry uses creativity, expertise, and talent from an individual to create the products that have benefits for living and value-added. In her professorship inauguration speech, Mari Elka Pangestu (2015: 6) mentioned that the creation of value-added can be identified using social asset, cultural asset, and the asset of creative human resources. Creative industry does not only create economical transaction, but also social and cultural transaction. It can be inferred that what is meant by value-added in this case is the social value, cultural value, and economic value.

As reported by the Ministry of Tourism and Creative Economy (2014b: 115-118), in the last four years, from 2010 until 2013, the statistics of the arts sector's workforce reached over seventy thousand people. There were 79,250 people from 24,236 businesses in 2013 alone. , This number is higher than that in the sub- 
sectors of music, information technology, fine arts, interactive games, advertisement, research and development, architecture, film, video and photography. However, the numbert of workforce in the performing arts is still lower than that of the other creative industry sub-sectors, namely radio and television, crafts, fashion, and culinary. It can be said that the performing arts sub-sector has the potential to evolve and support the growth of employment, because it does not stand alone but involves a large number of people such as performers, musicians, sound man, light man, stage crew, costume stylist and make-up artists as well as stage manager. In this regards, the contribution of performing arts is not limited to economic value but much more to social and cultural values.

The new trend in the performing arts industry is not in the form of recording like in the music industry, but it is in the form of festival. According to Tuti Levi, the context of the festival in the creative industry is not merely a form of celebration, but also identity, community (2003). These three aspects were mentioned by Titus Levi (2003) in the booklet discussing festivals in Los Angeles, United States. Levi (2003) expressed that if festivals are merely celebrations, then the festivals can turn inward and reinforces a sense of home rather than connecting and reaching out. The role of community is imperative for the festival. The community makes connection with each other, builds a community, and presents the works of the community. For the artist community, the festival provides a space to showcase their works and to collaborate with other artists as well as to learn about each other's works (2003: page). Furthermore, the festivals can reinforce group identity (Getz 2010). The festival in the context of performing arts market functions simultaneously as social, cultural, and economic investment.

Some festivals are identified as a market, which whose goal is to showcase, to pitch, and to exhibit performing arts and to facilitate the artists in making connection and networking with stakeholders, such as promoters, curators, festival directors, and venue presenters. Here, I identified some festivals which use the term "market", namely Australia Performing Arts Market (APAM) in Australia, Tokyo Performing Arts Market (TPAM) in Japan, Performing Arts Market in Seoul
(PAMS) in South Korea, and Indonesia Performing Arts Market (IPAM) in Indonesia. The festivals that do not use the term "market" are PANNZ (Performing Arts New Zealand) in Auckland, Conference Internationale des Arts de la Scene (CINARS) in Montreal-Canada, Assembly Festival and Edinburgh Fringe Festival in Edinburgh, United Kingdom. I visited three festivals abroad, namely PANNZ in March 2013 in Aukland, Assembly Festival and Edinburgh Fringe Festival in the United Kingdom in August 2014, and PAMS in South Korea in October 2015. Also, I facilitated IPAM in November 2013 and helped the artists in preparation for their UK National Tour 2015.

This article aims to explore the concepts and practices of the organization of performing arts in the context of creative industry. Hence, I conducted an in-depth qualitative analysis using a case study method. As explained by Yin (2003), case study has two ways of conducting in-depth research: inside the case itself which is called intrinsic case study, and researching the case as well as the context in which it comes along, or what is called collective case study. Two cases presented in this article are: Indonesia Performing Arts Market (IPAM) 2013 in Indonesia and Performing Arts Market in Seoul (PAMS) 2015 in South Korea. The techniques of data collection used were participatory observation, interview, literature review, and personal reflection. I already discussed those two festivals in the national seminar in Bandung, focusing on how to develop a strategy to increase the role of educational institutions in performing arts (Masunah, 2015). This article is more concerned with the questions: How is performing arts market conceptualized and practiced in Indonesia and South Korea? Are there differences and similarities? I argue that the similarities lie in the concept of globalization, and the differences are in the practices of managing the festival in the country and post-festival abroad.

\section{FINDINGS AND DISCUSSIONS Performing Arts Market (PAM) in the Concept of Globalization}

The concept of performing arts market pertains to globalization. However, it is different from the concept of globalization in the field of 
economy that implies an integrated world market or one market as its goal. The basic concept of globalization in the performing arts market is the world society that recommends non-integration or differences. This concept is related to the view point of Urlich Beck who states that the world society is similar to globality as individuals have personal and cultural connection, but they still maintain their differences (2003: page). Beck particularly states:

...world in the combination 'world society' thus means difference or multiplicity, and 'society' means non-integration so that... world society as multiplicity without unity. ...Globalization, on the other hand, denotes the process through which sovereign national states are crisscrossed and under minted by transnational actors with varying prospects of power, orientations, identities, and networks (2003:10-11).

$\mathrm{T}$ (his) concept of globalization can be identified in the cultural production and goals of performing arts market.

The term performing arts market contains two words: performing arts and market. Performing arts is a cultural production maintaining dance, music, and theater. They are intangible arts, moving in space and time. They can be seen, they can be heard, and we are getting feeling and experiences, but they could not be touched. Performing arts involves people as performers and supporters. In the book of creative economy strategic plan 20152019 published by the Ministry of Tourism and Creative Economy (2014b: 85), performing arts is defined as:

A branch of arts that involves designers, workers for technical parts, performers who express the ideas to the audiences in the forms of oral presentation or music or fine arts, expression or body movement or dance in the live performance in the same space and time, here and now.

I should call performing arts as "collective arts" because of the complexity of art elements in it. Since the time when our economy was still concentrated on agriculture, performing arts has become a part of the ritual and celebration which is considered as offerings ceremony. In the era of industry, performing arts has shifted toward the secular purposes, prioritizing mass entertainment while remaining to be accompanied by the creation of contemporary arts. When the information and technology become parts of our lives, the performing arts flourishes with the technology, and now it is shifting to creative economy, where human creativity is the source for developing capital. In the creative economy era, performing arts does not only serve as the field to express our aesthetic experiences and to find symbolic meaning alone, but also to increase value-added socially, culturally, and economically. Here, it shows that the shift of performing arts' functions in our lives is very dynamic: from ritual to secular, from agricultural orientation to industrial one.

Meanwhile, the term market is connected to trade and economic aspects. The characteristic of a market is the presence of sellers and buyers. In the context of performing arts market, the sellers are similar to performers, producers, managers, groups of performing arts, organizations of performing arts, while buyers are stakeholders such as festival directors, artistic directors, curators, and venue presenters. Buyers are important to distribute performing arts to audiences all over the world.

The goals of Performing Arts Market in Seoul (PAMS) as stated in the official website are as follows:

The primary objects of PAMS are revitalization of rational distribution and exportation to overseas markets for Korean performing arts that is based on diversified orientation and creation. Through the diverse programs of PAMS as showcased by selected performing arts, booth exhibitions for the promotion of art works and artistic groups, varied symposium and networking programs, all the performing arts experts are able to share the information of field and global trends for encouragement of creation and provision of performing arts.

Not only complacent as distributive channel of polished art works, PAMS also desires to expand the boundary of creation and distribution by offering inspiration for cooperation through intensive communication. PAMS 2015 
suggests a solid vision as the representative contemporary performing art markets of Asia. (Retrieved from http://en.pams.or.kr/ pams/pams01.asp ).

In the guidelines book Number: PT.03/UM.001/D. EKSB/Kem-Par/2014 concerning Indonesia Performing Arts Market (IPAM) written by Directorate General of Creative Economy based on Arts and Culture (2014), part I, point C, the goals of IPAM are stated below:

- To facilitate a meeting between performers and producers with festival directors and venue presenters from around the world;

- To facilitate stages for innovative and high quality Indonesian performing arts presentations which have competitiveness and international standards;

- $\quad$ To provide space for stakeholders from around the world to learn more about Indonesian performing arts;

- To facilitate investors from around the world to produce and promote Indonesian performing arts;

- $\quad$ To provide an opportunity for performers and producers to make collaboration between Indonesia and countries abroad in the future;

In summary, the term performing arts market is defined as an event that presents and promotes selected and innovative performing arts productions to be distributed, and facilitates collaboration and exchange of ideas among professional artists and performers in the field of performing arts.

Moreover, in the performing arts market two activities are arranged: The first is holding festivals in the country to exhibit selected performing arts, and the second is arranging tours as the results of negotiation during and postfestival. Actually, touring abroad is the main target for producers. Tour is the implementation of the concept of globalization where the people along with their cultural production and identity of the country can be presented. In the tour, the people who represent their country have cultural diplomacy. To borrow the concept of globalization from Beck, the tour is similar to the concept of "transnational space" (2003: 26-27). The stages abroad featuring performing arts from other countries do not only serve as aesthetic presentation but also social and cultural presentation, where a dialogue of ideas across countries takes place.

\section{Indonesia Performing Arts Market (IPAM) 2013}

\section{a. Preparation and Implementation}

Indonesia Performing Arts Market (IPAM) is the festival facilitated by the central government in the national scope. The first IPAM was conducted by the Ministry of Tourism and Culture of the Republic of Indonesia in 2003. It was held annually until 2005. Then, it became a biennial festival in 2007 and 2009 (Masunah, 2014). It was only four years later, or in 2013, that IPAM held its sixth festival under the new ministry in the Soesilo Bambang Yudoyono Cabinet II, the Ministry of Tourism and Creative Economy. Under this new ministry, IPAM was made one of the promotional programs of the Directorate of Performing Arts and Industry of Music Development, Directorate General of Creative Economy based on Arts and Culture in 2012-2014. The purpose of IPAM 2013 was to promote selected and curated Indonesian performing arts in terms of traditional, popular, and contemporary creative productions. The final goal was to export them to the festivals, fringe festivals, and important stages in the world.

During preparation of IPAM 2013, there were two main activities, namely a selection process of Indonesian performing arts and invitation to buyers. For these activities, the Directorate had people who worked as producer, consultant, and artistic boards. The consultant of IPAM 2013 was Andrew Ross, a former Director of Brisbane Powerhouse from Australia. His presence in Indonesia was supported by AusAID, Australian Embassy in Indonesia. He had experience as a buyer in IPAM 2004, and he collaborated with Nan Jombang Dance Company led by Ery Mepri from Padang, West Sumatera. In IPAM 2013, Andrew's role was to give recommendation in the selection of performing arts production and buyers. The artistic boards consisted of Ubiet and 
Eki Puradireja from Jakarta, as well as Ery Mepri from Padang. The role of the artistic boards was to select the performing arts to be performed in IPAM 2013. A producer, Rama Thaharani, worked with the consultant to invite buyers and manage the program of IPAM 2013.

The preparation of IPAM 2013 began in 2012. At that time, the Directorate collected performing arts videos which were sent by the artists. Then, the artistic boards and the consultant selected the best among them. They also picked some groups who did not send any videos but had high qualities of performance in dance, music, and theater. In total, there were 31 groups in IPAM 2013, consisting of 12 dance companies, 5 theater companies, and 14 music groups (Ministry of Tourism and Creative Economy, 2013). The producers invited 10 companies to the booth exhibition. The dance companies were Nan Jombang, Mugiono Dance, Soerya Soemirat from Mangkunegaran Palace in Surakarta, Choreographer Hartati, Fitri Setyaningsih, Iik Suryani, Melki J. Neolaka, Ika Nurdita Larasati, Dance Lab. Community, Sanggar Obor Sakti, and Indra Jubir. In the field of theater, there were Teater Garasi, Papermoon Puppet Theater, Garin Nugroho with Opera Jawa, Ki Slamet Gundono and Wayang Suket community, and Komunitas Hitam Putih. The music groups were represented by Qua Etnika, Sinten Remen, Ul Daaul Madura, Music Banyuwangi, Riau Rhythm, Gus Teja, group Kande, Eyuser, Dewa Bujana, Simak Dialog, Endah \& Rhesa, Adhitya Sofyan, and Ubiet and Dian H.P. with their composition of "Delapan Cinta." Three hundred people in total performed in IPAM 2013. They came from 11 regions in Indonesia: Aceh, Bali, Banten, Jakarta, West Java, East Java, Central Java, Papua, Riau, West Sumatera, and Yogyakarta.

Buyers or delegates were festival directors and venue presenters from Indonesia and abroad. Delegates from Indonesia include 33 leaders of cultural centers and chiefs in the field of arts and cultures from the cities and districts that do not have cultural centers. Meanwhile, 38 people were listed as delegates from abroad, namely from the United States, Australia, Belgium, the United Kingdom, Ireland, Japan, Germany, Canada, South Korea, Malaysia, Poland, and Singapore. Foreign Institutions that supported delegates coming to Indonesia were the British Council, Goethe Institute, Australian Embassy, Canadian Embassy, and Poland Embassy.

IPAM festival was held on November 13-16, 2013. It spread out in six places in Jakarta such as Restaurant Payon Kemang, Salihara in South Jakarta, Theater Kecil Taman Ismail Marzuki (TIM) Jakarta City, Red/White Lounge Kemang, and Goethe Haus Goethe Institute Jakarta, as well as Balai Kota Jakarta. The main activities in IPAM 2013 were showcasing, pitching, seminar, and networking.

The first day of IPAM 2013 was the opening ceremony that was presented as a two-hour dramaturgic performance at Payon Kemang Restaurant. Ul Daul Madura music was presented as a carnival which accompanied delegates walking from their hotel to the location of the event. When the delegates arrived at Payon Restaurant, the sound of Banyuwangi music was simultaneously played to welcome delegates to enter the ceremony location. The Mangkunegaran dancers then showed up with their delicate movements accompanied by gamelan music. After about fifteen minutes, the Royal Classic dance performed, then, one of Director Generals from the Ministry of Tourism and Creative Economy delivered a speech for this opening ceremony. Afterwards, Fitri, Hartati, Soerya Soemirat Dance Company, and Jadug Ferianto showcased their performance.

On the other two days, the contemporary performers performed their arts for around 30 and 60 minutes in Theater Kecil Taman Ismail Marzuki (TIM), Theater Salihara, and Goethe House. In Balai Kota Jakarta, the traditional performing arts of Betawi were performed during dinner time as part of the governor's invitation. Because of the greatly varied showcases and different venues, IPAM 2013 received great responses from delegates. Their responses were expressed on the final night of the event, on November 16, 2013, when they met the Minister Mari Elka Pangestu. Part of their discussion was reported in the newspaper, The Jakarta Post, titled "Showcasing the best of Indonesia's" (Mariani, 2013).

A pitching session or a presentation forum was conducted for the works which had not been fully completed or were still half-finished in order to attract interest from the buyers or investors. 
Furthermore, a seminar was held between the artists and producers in order to increase their understanding on the practices of international tours, including the skills of the preparation, promotion and packaging of the work, also of negotiating and managing international tour. Networking session was specifically conducted in the café of Indra Lesmana's, Red/White Lounge Kemang. Indie music was a part of the performances in this Lounge. The producers, managers, and performers were encouraged to interact with foreign delegates in this event. Not only did the delegates make contact and dialogue in the Café, but they were also encouraged to participate in the whole IPAM activities. Therefore, the artists who did not perform in IPAM were invited to present their work and communicate with delegates because building networking in IPAM was the most important activity for the performers and producers.

The important thing occurring at IPAM was the interaction between performers and producers and stakeholders, where they introduced themselves by exchanging name cards or profiles as well as actively communicating with delegates as buyers. Unfortunately, probably because such occasion was something rare for Indonesian performers, not many of them could have negotiation and dialogue with the foreign festival directors and venue presenters. Only a few performers who managed to have communication with foreign buyers took advantages from the opportunity given by IPAM to get networking with them.

\section{b. Post-IPAM 2013}

Delegates from abroad were interested in the works of Indonesian performing arts which were presented at IPAM 2013. Post-IPAM 2013, many of the performing groups went abroad. Riau Rhythm and Soerya Soemirat Dance Company were invited by buyers from Singapore in 2014. Mugidance was invited to Finland to collaborate with the artists from Finland in 2014. Nan Jombang went to the United States in 2015. Three groups such as Kande from Aceh, Soerya Soemirat from Solo, and Papermoon Puppet Theater from Jogja toured the UK in 2015. They were invited by Southbank Centre London, Wales Millennium
Centre Cardiff, Cryptic in Glasgow, and Edinburgh Fringe Festival in Scotland.

In 2014, Directorate of Performing Arts and Music Industry Development supported the groups of IPAM 2013 to join the UK National Tour 2015. Indonesia and UK built a Joint Working Group to plan and implement the program and activities in the creative industry sector. The British Council in Jakarta is a representative of the UK, and the Ministry of Tourism and Creative Economy was a representative of Indonesia. This Indonesian ministry became the leader for all activities related to the MoU. The sub-sector of performing arts was very active in having discussion with the British Council. In 2013, the British Council supported Art Summit Indonesia by sending a group named "Gandini Juggling." The British Council also participated in IPAM 2013 by inviting 6 festival directors from UK.

For the UK National Tour preparation, I led a Joint Working Group Meeting in London on August 29, 2014. Members of the meeting were representatives of Indonesian Embassy in UK, British Council in UK and Indonesia, and presenters from London, while representatives from Cardiff, Glasgow, and Edinburgh joined via a teleconference. Before the meeting, from August 22 to 28, 2014, we went to Edinburgh and GlasgowScotland, Cardiff, and London. The delegates from Indonesia included Rama Thaharani, Levina from the British Council of Jakarta, Yulianus Liembeng, and myself. We visited Edinburgh, Glasgow, and Cardiff to meet four presenters. We also observed the venues and visited the festivals and met individually with Directors for Assembly Festival, David Sloan and William Burdett-Coutts, Artistic Director and producer Cryptic Cathie Boyd and Claire Moran, Program manager of Wales Millennium Centre Louise Miles-Crust, and creative producer of Southbank Centre Rachel Harris, as well as program arts manager for the British Council in London, Carole McFadden.

In the Joint Working Group meeting, we discussed the schedule and the responsibility of each party in terms of budget. We offered five groups to perform in UK namely Kande group from Aceh, Papermoon Puppet Theatre from Jogjakarta, Music Group Adhitia Sofyan from 
Jakarta, Soerya Soemirat Dance Company from Surakarta, and Riau Rhythm from Riau. The Director of Assembly Festival in Edinburgh proposed to invite Kande from Aceh, Papermoon Puppet Theatre from Jogjakarta, and Music Group Adhitia Sofyan from Jakarta to perform from August 5 to 30, 2015. The Southbank Centre in London, Cryptif in Glasgow, and Millenium in Cardiff wanted to create a mini festival with Soerya Soemirat Dance Company and gamelan Mangkunegaran, Kande group, and Papermoon from September 4 to 20, 2015. Riau Rhythm proposed to perform in Edinburgh Fringe Festival. The reason the festival directors chose the groups was because of the originality and uniqueness of their Indonesian creative works. The meeting discussed the budget, in which it was agreed that Indonesian government would cover international airfare and preparation for the groups, while hospitality and performance fees and daily allowance would be covered by presenters in the UK.

After Joint Working Group meeting in London, I led the meetings in Jakarta with the local governments and the British Council of Indonesia. On October 1, 2014, I gathered five local governments to inform the results of the meeting in London. I asked them as well to support the groups' production and provide local transport, while The Ministry of Tourism and Creative Economy would assist in preparation and the international trip. The British council would cover publication. The representatives from the local governments agreed to support each group to have a tour in UK in 2015.

On October 20, 2014, the new President of the Republic of Indonesia announced the new cabinet in the new structure of his organization. We were surprised that the Ministry of Tourism and Creative Economy no longer existed. The Creative Economy was removed, and it becomes only the Ministry of Tourism. The Creative Economy Institution was established in January 2015 accordingly. Changing institutions caused a change in creative economy programs, particularly regarding the budget for UK National Tour 2015. The process of negotiation with the Indonesian government was a hectic one because they were in transition from the Ministry of Tourism and Creative Economy to the new Ministry of Tourism, while the Creative Economy
Institution could not contribute for the funding to UK National Tour 2015.

Fortunately, the Ministry of Tourism, the Ministry of Education and Culture, The Local Government of Aceh, Indonesian Embassy in London, and the British Council in Indonesia worked together to make the UK National Tour 2015 possible. At that time, Rama Thaharani and I were pointed to coordinate the groups of artists and communicate with the presenters in UK. The reason to choose Rama Thaharani was because she was a producer for IPAM 2013, and she joined the preparation for UK National Tour 2015; in addition, she led the community of Seni Sini Sana (Arts here and there). Only two groups got funded by the central governments, namely Papermoon and Kande, while Soerya Soemirat Dance Company was supported by the British Council. Aditya Sofyan and Riau Rhytm were cancelled because there was no support from the local governments.

The presenters in UK had already scheduled the Indonesian groups in their programs since 2014. The Assembly Festival in Edinburgh Fringe Festival canceled the groups from Indonesia to present in their venues because the groups took such a long time to respond to financial commitment deadlines. Three venues were still holding the venues for Indonesia. Rama Thaharani looked for other venues in Edinburgh Fringe Festival to have access to the international market in the UK. Thaharani got C Venues in Edinburgh for Kande and Papermoon groups, while Soerya Soemirat did not perform in Edinburgh. Then, these three groups performed in mini festivals in Cryptic-Glasgow, Wales Millennium Centre in Cardiff, and Southbank Centre in London.

According to Rama Thaharani's report (2015), UK National Tour 2015 with the tag line of "Discover Indonesia" was successful. The first location was Edinburgh, so the festival was called Edinburgh Fringe Festival. Kande performed daily in C1 Venue from 19 to 31 August 2015 at 19.30, while the Papermoon Puppet Theater performed in C2 Venue everyday from 15 to 31 August 2015 at 22.10. Kande and Papermoon were two groups out of the 3,000 groups performing in the 250 venues in this festival. Edinburgh Fringe Festival was the 
biggest performing arts festival in the world which has been held after World War II since 1947.

After performing in Edinburgh Fringe Festival, Kande and the Papermoon along with Soerya Soemirat Dance Company performed in three other cities, namely in London (September 4-6 $\left.6^{\text {th }}\right)$, Glasgow (September 9-13 ${ }^{\text {th }}$ ), and Cardiff (September 16-20 ${ }^{\text {th }}$ ). According to Thaharani (2015), the tickets for their performances in the three cities were always sold out. Cryptic in Glasgow held a mini festival, "New Pathway," that included other groups such as contemporary music "Senyawa", fine artist Jompet Kuswidananto, photographer Jim Allen Abel from Jogjakarta, film maker Vincent Moon, and Gunawan Muhamad from Salihara, Jakarta. The mini festival "Discover Indonesia" in Glasgow had various venues such as Centre for Contemporary Arts, Glue Factory, Glasgow Film Theatre, Glasgow School of Arts, Royal Conservatoir of Scotland, The Burrell Collections, and Kelvingrove Art Gallery and Museum. Media in the UK reported "Discover Indonesia" and "Wonderful Indonesia" in AugustSeptember 2015.

\section{Performing Arts Market in Seoul (PAMS), South Korea}

\section{Preparation and Implementation}

Performing Arts Market in Seoul (PAMS) is an international festival that presented local cultural production from South Korea and collaborative production between Korea and other countries, as well as the production from foreign countries. However, PAMS mainly showcased the performing arts from Korea. This festival has been annually held every October since 2005. The festival is held by the non-profit organization of Korean Arts Management Service (KAMS) supported by the Ministry of Culture, Sport, and Tourism of South Korea. In addition, KAMS organized the Traveling Korean Arts Plus program to support the groups from Korea to have a tour after PAMS event. KAMS collaborates with Korean Cultural Center (KCC) in the respective country to bring the groups from Korea to other countries.

While during IPAM 2013 in Indonesia, I acted as the head of committee and a facilitator for the performing arts groups, in PAMS 2015 I acted as a buyer and representative from Indonesia who was invited by Korean Cultural Center Jakarta and KAMS. There were 10 delegates from $\mathrm{KCC}$ from all over the world and Korean Embassy in Indonesia who came to PAMS 2015. They were from Indonesia, Brazil, Vietnam, Los Angeles (USA), Hungary, Turkey, Argentina, Thailand, Sydney, and Iran. My goal in accepting the invitation from KCC and becoming an observer in PAMS 2015 was to gain knowledge and experience about South Korean performing arts. This knowledge can be used as teaching materials in the university; to give recommendations on performing arts works from South Korea to festivals' directors in Indonesia; to bridge relationship between the institutions, festival directors, venues, and performing arts groups; and to improve the knowledge and understanding of performing arts industry in South Korea.

PAMS 2015 was held on October 5-8 ${ }^{\text {th }}$, in Seoul. The theme of the event was "Extension \& Connection" (KAMS, 2015). During the fourday event, I got experiences on performing arts in South Korea through seminar presentation, performance (showcases of PAMS's Choice), pitching, networking, and visiting Arts Centers. Seminar presentation was arranged for the delegates of Korean Cultural Center. Creative Director Seok-gyu Choi presented the history of performing arts in South Korea. It surprised me that Korea, according to Choi's presentation, has 732 theaters and 927 halls that can accommodate from 75 to 2,000 audiences. Artistic Director Jaejin presented a strategy for building relationship on contemporary performing arts between countries. We also visited three art centers, namely Seoul Art Center, Doongso Art Center, and National Gugak Center.

The showcasing in PAMS presented 13 selected pieces of performing arts from Korea, such as music, dance, theater, and collaborative works between design and performing arts. KAMS also arranged for us to watch PAMS' Choices. The venues were in Dongsoong Hall, Studio Theater, Kokdo Theater, and Seoul Street Art Creation Center. I was interested in "Parkpark," "Quartet of pain", "Dance, she is grazy," "Stranger's song", and "Things that Remember 2015." I also watched the traditional music and dance in the National Gugak Center. The performance was 
very interesting with the artistic stage and the seats for audiences in traditional Korean style. Besides the performing arts from Korea, I also watched international showcases from Hong Kong, Spain, and Cambodia. PAMS 2015 had focus countries from ASEAN to participate in the event, such as Cambodia, Singapore, and Vietnam.

Pitching sessions were conducted in two locations in two days. The sessions presented dance, music, theater, and collaborative arts works by Yeon-hee Company U-hee, Park Na Hoon Park Company, Play Factory Mabangzen, Jeong Ga Ak Hoe, Art Stage San, Breishit Company, Goblin Party, and Indang's Blues. To facilitate collaboration among groups, producers, and associations and among performers, and buyers, KAMS arranged networking sessions such as booth exhibition, roundtable discussion, speed dating, PAMS Buddy, and PAMS' Night. Booth exhibition consisted of 69 stands. Groups, organizations, and associations from Korea and around the world like China, Spain, Australia, Finland, Canada, Hong Kong, New Zealand, and so on exhibited their performing arts productions and programs. Speed dating was a part of booth exhibition in which delegates had a short meeting. Some of the delegates also brought the groups to perform in the hall or theater in Seoul. The booth exhibition was crowded. It looked like a market, where there were buyers asking questions to the people in charge of the booths. This situation continued to PAMS's Night.

PAMS Buddy was an information session about funding agencies. KAMS and Center Stage Korea presented their programs to manage the groups from Korea post-PAMS. The people from Korea were aware that the groups who will be invited by other countries need to be supported financially. The government in Korea provides funding to support the groups managed by KAMS, Center Stage Korea, and Korea Cultural Center (KCC). Therefore, the groups invited by other countries can get funding from these organizations.

\section{Post-PAMS 2015}

In Post-PAMS 2015, I gave recommendations on the selected groups to be invited to the festivals and venues in Indonesia. As a buyer and representative from Indonesia who was officially invited by Korean Cultural Center (KCC) and KAMS, I selected the groups from PAMS 2015 to come to Indonesia. There was an interesting theater group from pitching session which would be appropriate for Art Summit Indonesia (ASI). The theater group presented "Hong do" from Mabangzen. Hong do tells about the traditional Korean version of Romeo and Juliet. I recommended this group for the upcoming Art Summit Indonesia because in ASI 2013 Korea presented "Bulssang”, a contemporary dance created by Korean National Contemporary Dance Company (KNCDC). ASI 2013 was organized by the Ministry of Tourism and Creative Economy, while the upcoming ASI will be held by the Ministry of Education and Culture in Jakarta.

Furthermore, I selected Na Hoon Park Dance Company to be presented in Solo International Performing Arts (SIPA) in Surakarta. Na Hoon Park created a contemporary dance called the "Three Doors and the Two Mirrors." SIPA Director, Irawati Kusumorasri, agreed to choose Na Hoon Park as one of the performers for the event on September 8-10 ${ }^{\text {th }}, 2016$.

From showcases, I selected three groups such as "Parkpark", a vocal music grounded in traditional Gugak but the music is created in the contemporary style. This music was presented in the opening of PAMS. Other two pieces were contemporary dances called "Quartet of Pain" and"Dance, she is Crazy". Minhee Park, the creator of "Parkpark" will be invited by the Fakultas Pendidikan Seni dan Desain (FPSD) or Faculty of Art and Design Education, Universitas Pendidikan Indonesia (UPI), to give a workshop, and the result of the workshop will be performed in the First Bandung Isola Performing Arts Festival (BIPAF) in October 2016. This festival will be held in cooperation with the Local Government of Bandung City. Korean Cultural Center in Jakarta supported international trips, while UPI covered hospitality. In the beginning, FPSD proposed a grant to Center Stage Korea by filling in the application form. Unfortunately, FPSD's proposal was not accepted. Then, Korean Cultural Center (KCC) in Jakarta took care of the funding for "Parkpark". In summary, two performing arts groups from PAMS 2015 will perform in Indonesia in 2016. I become a contact person for 
the two groups to communicate with the festivals in Indonesia. Other groups I recommended to other festivals could not be followed up in 2016 .

\section{CONCLUSIONS}

The similarities of the implementation of the performing arts market in IPAM 2013 in Indonesia and PAMS 2015 in South Korea lie in the concept of globalization with world society orientation and the target. The target of these performing arts market is domestic festivals and international tour or transnational space. The forms of festivals in IPAM and PAMS accommodate showcasing and pitching of curated performing arts in the respective country, as well as facilitating networking. The tour is one of the forms of the implementation of cultural diplomacy and cultural performances and also a form of transnational dialogue for the audience to experience other cultures. Furthermore, the tour can ignite creative imagination. The artists or performers will gain social, cultural, and economic values.

The differences between IPAM 2013 and PAMS 2015 are in the number of group participants in showcasing, the organization which held the event, and the post-performing arts market strategies, as well as the attitude of the performers and producers. The scope of IPAM 2013 was national, showcasing 30 performing arts groups from Indonesia; meanwhile, the scope of PAMS 2015 was international, including the focus countries. In terms of the number of participants, there were 12 participating groups from Korea, whereas in the booth exhibition PAMS presented performing arts from around the world. Meanwhile, in terms of the organizing institutions, IPAM was organized fully by the central government, while PAMS was held by the organization of Korean Arts Management Service and funded by the government, particularly the Ministry of Culture, Sport, and Tourism and Bank Industry Korea. The performers and producers in Korea show progressive attitudes to networking, which is in contrast to Indonesian performers who were more passive in networking. The networking session in PAMS was arranged in various events such as booth exhibition, roundtable discussion, speed dating, PAMS Buddy, and PAMS' Night. All the performers in PAMS 2015 presented in all networking sessions to have a dialogue with and give their profile and name cards to buyers.

Post-IPAM 2013 did not receive sufficient attention from the organization or the institution in Indonesia, because the institution that held the event had changed, and no other organization and institution took responsibility to follow up postIPAM. On the other hand, PAMS has a sustainable organization that takes responsibility for the follow up of post-PAMS. The groups which were selected by buyers abroad have an opportunity to get funding for their tour. KAMS is responsible for expanding the groups to other countries, outside Korea. In several countries in the world, KCC have representative offices to support and organize the groups from Korea in the respective country. In addition, PAMS has continued to be held annually until today, while IPAM is not organized regularly; it unfortunately depends on the central government's changing policy.

\section{REFERENCES}

Beck, Ulrich (2003). What is globalization? [Camiller, P., Trans.]. Malden, MA, USA: Blackwell Publishing Inc.

Cunningham, Stuart D. and Higgs, Peter L. (2008) Creative industries mapping: where have we come from and where are we going? Creative Industries Journal, 1(1). pp. 7-30.

Directorate General of Creative Economy based on Arts and Culture, The Ministry of Tourism and Creative Economy (2014). Petunjuk pelaksanaan/teknis penyelenggraan Indonesia Performing Arts Market (IPAM) (The technical guidelines for the organization of Indonesia Performing Arts Market). Jakarta.

Getz, D. (2010). The nature and scope of festival study. International Journal of Event Management Research, 6(1), 2010.

Korean Arts Management Service (KAMS). (2015). Performing Arts Market in Seoul 2015 (Programme book). Seoul.

Levi, T. (2003). Festivals: Their meaning and impact in the City of Angels. In About festivals. Los Angeles: Center of Cultural Innovation.

Mariani, E. (2013, November 26). Showcasing the best of Indonesia's. The Jakarta Post. Retrieved from http://www.thejakartapost. com/news/2013/11/26/showcasing-bestindonesia-s.html 
Masunah, J. (2014). Program dan kegiatan Direktorat Pengembangan Seni Pertunjukan dan Industri Musik 2014 (Programs and activities of Directorate of the Development of Performing Arts and Music Industry 2014). Jakarta: Directorate of the Development of Performing Arts and Music Industry, Ministry of Tourism and Creative Economy.

. (2015). Strategi pengembangan seni pertunjukan dalam konteks industri kreatif (The strategy of developing performing arts in the context of creative industry). (Paper presented in a seminar). Bandung.

Ministry of Tourism and Creative Economy (2014a). Ekonomi kreatif: Kekuatan baru Indonesia menuju 2025 (Creative economy: The new power of Indonesia towards 2025). Jakarta.

- (2014b). Ekonomi Kreatif: Merancang Aksi Jangka Menengah 2015-2019 (Creative economy: Designing Medium Term Action Plan 2015-2019). Jakarta.

(2013). Indonesia Performing Arts Markets (IPAM) 2013 programme. Jakarta,

Pangestu, M.E. (2015). Globalisasi, kekuatan ekonomi baru dan pembangunan berkelanjutan: Implikasi terhadap Indonesia (Globalization, new economic power, and sustainable development: Implications for Indonesia). (Inauguration speech for the professorship). Jakarta: Universitas Indonesia.

Performing Arts Market in Seoul (PAMS). Retrieved from http://en.pams.or.kr/pams/new_pams01. asp

Thaharani, R. (2015). Discover Indonesia, UK National Tour 2015. (unpublished report). Jakarta.

Yin, R. (2003). Case Study Research: Design and Methods ( $3^{\text {rd }}$ edition). Sage Publication: Thousand Oaks, California. 